\title{
Introduction to the Handbook on Religion in China
}

Stephan Feuchtwang

As you read this Handbook you will see that many expectations raised by the word 'religion' are misleading. You may be led in directions you may not expect. Did you expect a set of distinct institutions and an organizational hierarchy with an ultimate authority and its representatives on earth, such as a church? Well, there are schools of Daoism and of Buddhism, the passing down of the teachings of masters and their followers, the mystery and wonder (of the Dao as distinct from Creation), the training of devotees in what you can call monasteries and seminaries, whose residents have accepted precepts including that of celibacy. But these textual traditions and their claims to immanence and transcendence do not usually claim congregational flocks of the faithful, as do denominations and sects of the monotheistic religions, Judaism, Christianity and Islam. Now, under the influence first of Christianity and imperialism, then under the influence of a conception of religion and superstition written into the Constitution and the policy of republican Chinese governments, Buddhism in particular has developed institutions that can seem like a church. And there were reformers who wanted to turn Confucianism into a religion of China to combat the supremacy of the Christian powers. But the teacher-student, master-disciple relationship is still prevalent in the transmission of Buddhist and Daoist religious and ritual traditions even as they transform themselves.

The monotheistic religions do exist in China, as such and in Chinese reinventions too. But the ritual marking of the phases of life, birth, marriage and death, for the vast majority of people living in China, does not occur in such institutions. Performances of these and other rituals conform to their own transmission, not to any doctrine or to any one textual tradition.

There is a more Chinese way of approaching them, namely the idea of rites $(l i)$ and the ideal of being governed by propriety, manners and the correct performance of the honouring of elders, of ancestors and of exemplary historical figures. But these do not include the rituals for which Daoist ritual experts, most of whom are lay and in families that 


\section{Handbook on religion in China}

hand down their expertise and disciplines, are employed. So, religion in China, as you will see from the table of contents for this Handbook, covers a field wider than you may expect. But we can say that the wide and varied topic of 'religion' in China is always, as rituals and religions are everywhere, about ways of transmitting and forming moral personhood, transcendence and immanence. They coexist with such secular institutions as schools and families and trust in the empirical sciences. We can also say that one outstanding feature of religion and ritual in China is that it extends in different ways to a universe governed by principles of change and consisting of circuits of vital and substantial energies $(q i)$. Their compatibility, or not, with the physics, chemistry, biology and astronomy taught in schools and furthered in institutions of research, is one of the main features and topics for this Handbook on religion in China.

\section{RELIGION UNDER A SECULAR STATE}

This Handbook is about contemporary China, so it must also include the secularity of governmental policy, which is quite different from that of the old, imperial governance of and by rites. The People's Republic of China (PRC) has a constitutional policy on 'religious belief', much indebted to the Euro-North American conception of religion, in which adherents to a religion can be counted and membership is a matter for private belief. In the Chinese context the implementation of this policy has caused many problems, beyond those faced by all secular states where 'private' religion overflows hugely into public life. In the PRC, secular government of religion has special features that include the difficulty of categorizing rituals that do not belong to any one religion but can easily be deemed contrary to official ideology. Practices of divination, recreation and healing can be deemed unscientific and fraudulent and therefore subject to criminal law. On the other hand, the PRC government has a stronger than usual policy on culture, that is both prescriptive and quite flexible. Like all policy it constantly evolves and is adapted in its implementation, treating ritual and religion as culture or as heritage, or not, and adding its own state rituals as elements of its political culture. Intrinsic to this cultural policy is the celebration of what is presented as long-lasting civilization giving China its unique national characteristics and, at the same time, as with other nations, its principles for universal governance. But instead of being a constant adaptation of an ancient set of unchanging principles of change for 'everything under heaven' (tianxia), its temporality in this new form is future-oriented, as a 
new China emerges capable of global governance. Instead of a set of classical texts on self-cultivation, self-restraint and responsiveness, of rites and sage rule, there have been a series of reinterpretations of those same classics in and for the new temporality of modernization accompanying invented traditional rites to venerate the sage Confucius as the embodiment of Chinese national character.

This secular culture is the context within which we have to understand contemporary religion in the mainland of China. With a less deliberate cultural policy and quite different politics in the equally secular governments of Taiwan and among overseas Chinese in their countries, similarly, we have to understand the further ramifications of contemporary Chinese rituals and religions. We have as everywhere to understand how religions and ritual practices and associations have been adapted to the growth of capitalist economy, participation in commercial enterprise, to dwelling in cities, and to different nationalisms, secular governments, and systems of mass schooling and the teaching of history, geography, and mathematized empirical sciences. All entail the new temporality of national narratives and the project of modernization.

The various kinds of expertise in ritual transmitted from imperial China present other temporalities, implied by the influence of the spirits of the dead and of deities and demons and conjunctures of fate. But they have to coexist, because they live in the same people who employ or wield such ritual expertise and the overarching cosmology of a universe of vital energy flows ( $q i)$ who are also entrepreneurs, have been to secular schools, have their personal visions and desires of belonging to a nation and its history, and their own aspirations to modernity. One result of this conjunction can be millenarian promises of abundance by prophets, of any religion or deity. Another can be syncretistic spiritual associations, their masters or the mediums of their masters, continuing in new adaptations the traditions of associations for moral regeneration and world healing. A third possibility is new versions of the religions of China, from Daoism and Buddhism to Christianity and Islam.

Most of the religions in the world exist in China, adapted to China's own Daoist and family rituals, adapting to each other; in the longest term, the making of Buddhism into a Chinese and Tibetan religion and its several schools and versions. In the rest of this Introduction, I will outline the contents and the way the Handbook is organized into four parts. ${ }^{1}$

1 Useful online bibliographies on Chinese religion are http://www.uni-leipzig.de/ clartp/bibliography_CPR.html and http://faculty.orinst.ox.ac.uk/terhaar/. 


\section{PART I: STATE POLICIES, CIVIC SOCIETY AND CULTURAL REVIVAL}

Part I sets the governmental and civil context in which religion, ritual and divination are practised in the PRC. Chapter 1 sets out the governmental policies on religion and superstition, and on their policing, modified by the interests of local governments promoting their cultural heritage and tourism. Tourism is a major industry, and most of it is fuelled by travellers from other parts of the mainland ( 5 billion from within China, compared with 270 million from outside China, in 2017). ${ }^{2}$

Control of religion is exerted by the system of registration through the 'patriotic associations' of self-funded institutions, of Buddhism, Daoism, Islam, Catholicism and Protestantism. Nevertheless, the great majority of more loosely organized activities and festivals are not registered but have been tolerated by local officials. At the same time, local officials seeking advancement can take more controlling initiatives on their reading of new statements from central state or Party decisions. So there is fluctuation between lenience and severity, both at the centre and locally. For instance, local authorities act under the policy of making religion a means of maintaining a moral order so long as it is 'Chinese', in which the State Administration for Religious Affairs at every administrative level has come under the authority of the United Front Department of the Chinese Communist Party, which itself has become much more tightly controlled under the 'core' leadership of General Secretary Xi Jinping. The Party has made religion and selective cultural transmission central to its unification of population, to maintain cohesion and define the meaning of Chinese socialism. Religion must be Sinicized, under this policy, which includes promotion of national Chinese festivals as before, and recruits popular beliefs (renjian xinyang) into the sacralization of the Chinese state and Party rule ${ }^{3}$ but now also curtails 'foreign' festivals such as Christmas despite their commercial value.

In the Tibetan Autonomous Region and other Tibetan areas the control of monasteries has been severe, with a permanent watch against loyalties to the head of the dominant Gelugpa school, the Dalai Lama in Indian exile. In regions that were populated by non-Han Chinese majorities in Tibet and Xinjiang it has long been policy to encourage immigration from elsewhere by Han, accompanied by investment for industrial and

2 China Daily, global edition, 7 February 2018 (accessed 15 January 2019).

3 For detail on the work of Chinese scholars promoting and skirting this policy see Vermander (2019). 
commercial development, from which the Han migrants are the main but not the only beneficiaries.

Treatment of Islam as a non-Chinese religion has become much more severe, along with the presumption of potential terrorism by Muslim populations. Not only have Haj pilgrimages to Mecca been curtailed under the Sinicization policy, but also there is the banning of Arabic script on mosque signs, the compulsion to fly Chinese national flags at their gates, and the repetition of the slogan, 'China first, family second', a political-religious mantra everywhere in China. Huge new additions to the re-education camps begun in 2014 have been opened in Xinjiang, in which Uighurs, Kazakhs and other Muslims have to relearn the basics of Chinese loyalty that they had already learned in school, and in which they can be detained indefinitely. Domes have been declared out of order on mosques elsewhere, just as crosses have been forcibly removed from church buildings. But the scale of the re-education camps in Xinjiang goes beyond Sinification elsewhere. It is a particularly draconian version of the policy of ethnic blending, as distinct from plurality, now being applied throughout China, but in Xinjiang including strong inducements to mixed marriage and the planting of Han Chinese lodgers in Uighur homes, who bring gifts of pork dumplings and alcohol to see whether their hosts wince when they eat or imbibe them, as signs of adhering to a foreign religion. There it is Hanification, the turning of Uighur and others' ethnic identity into that of the majority Han population in terms of eating habits, clothing and language. Muslims in Xinjiang have become a population suspected of terrorism. Draconian measures have been reinforced even as lesser measures in the past induced violent reaction, including some acts of terrorism. The closure of Arabic schools is not confined to Xinjiang, nor is the suspicion of beards, veils and modest clothing, but in Xinjiang these are signs warranting internment, including the shutting away of parents and the Sinification of their 'orphans' in special homes and schools, for the safety of the rest of the population of China, many of whom do feel they are threatened.

Buddhism is no longer treated as a foreign religion, rightly. But Islam and Christianity are, despite the fact that, like Buddhism, distinctly Chinese varieties of each have emerged in China. Unregistered churches have been bulldozed or just closed down. Priests and pastors have been told to lead their congregations in the singing of patriotic songs. As Chapter 1 details, the policy of Sinicization affects all 'religion' and 'superstition' in China, but most severely Islam, Tibetan Buddhism in Tibetan regions, and Christianity. Policing is far more intensive in Tibet and Xinjiang than elsewhere, but digital surveillance has been innovatively intensified everywhere. 
More details on the effectiveness of government policy will be found in Chapter 1 and in the chapters that follow, where it is relevant to their topics. Chapter 1 ends with a discussion of the situation of far looser controls in Taiwan and Hong Kong, wondering whether the PRC might eventually turn in their direction.

Chapter 2 is about charitable institutions based on religious precepts and on organizations that form important parts of civic society. They are subject to governmental controls while remaining desirable extensions of welfare. Republican China and Japanese colonial Taiwan (1895-1945) took secularizing, constitutional and missionary as models to reform the long-established organizations of worship and charitable institutions, to foster new charities, in separate civic organizations even though they might be linked with religious faiths or redemptive societies. Even when both linked and direct religious and temple-based charities were revived in the 1980s, they were what the authors call 'industrialised philanthropy': large in scale, autonomous, with a bureaucratic administration, and fostering among their volunteers and other supporters a new civic self.

Of all the chapters in this Handbook, this one devotes itself most to Taiwan, and this serves the purpose of showing how industrialized philanthropy in both China and Taiwan rely on a process the authors call 'political merit-making'. In China this is a defensive strategy, in which the charitable non-governmental organization (NGO) involves officials in its governance and adjusts its activities to support government objectives. In Taiwan, it is a collaborative strategy, in which the NGO supplements, expands, enables and extends governmental objectives.

Chapter 3 is another that emphasizes the making of a new self in civic society, more or less in accordance with that fostered by the official promotion of civilization and culture, but growing from the grassroots in various kinds of bodily and spiritual self-cultivation, often commercialized. Both top-down and bottom-up, they nurture claims to bring into modern life ancient disciplines and cultural resources. In addition the various movements have spread these technologies of body and mind globally. At the same time, others have brought into China similar technologies of the self from the United States of America and from India, combining them with Chinese disciplines. A strong characteristic of these fads and continuing practices is that they are indistinguishably both spiritual, referring to Chinese and other religious traditions, and secular, referring to culture and the state, combining aspirations to moral social redemption and individual material or entrepreneurial strength and success. 
Chapter 4 describes and discusses another moral redemption, the revival of Confucianism, a spiritual but not a religious tradition, although there have been attempts to turn it into a religion. The teachings of Confucius and his disciples have been transmitted and reinterpreted for two millennia and have been the basis for the imperial dynasties' orthodoxy of moral order. In reforms at the end of the dynastic state and the first republican revolution, they were reinterpreted again, but also rejected by more radical leaders as intrinsically backward. A version of Confucian order and the study of its classics continued and changed in Taiwan under the Japanese and then the Nationalist (Guomindang) regimes and Taiwanese teachers became an inspiration for some of the revival of Confucianism in mainland China from the 1990s onward. Chapter 4 provides abundant evidence that this was a grassroots revival before it was endorsed, in the 2000s, by many businesses and by local and central governments. They revive and remodel, or reinterpret, not just the study and reading of the Confucian classics, but also rites of passage, domestic and familial, and the national commemorative festivals of Confucius. Less known is the revival of one of the biggest redemptive societies (the subject of Chapter 9), the Yiguandao, with its emphasis on Confucian virtue and its conduct of Confucian rituals, in collaboration with government officials.

Finally in Part I, in Chapter 5 we come to the activities of cultural heritage where they include the buildings and practices of religious and other rituals. Cultural heritage and its preservation or its reinvention blurs distinctions between policy-makers' categories of religion and beliefs on one hand, and what officially might otherwise be targeted as superstitions on the other. But it does cause tensions between different agencies of government, and between them and local practitioners and participants. This chapter tellingly illustrates by brief case studies how several agencies and convictions are combined, including the mixture of tourism, pilgrimage and local ritual efficacity, and how some revived customs have attracted local participants, whereas in probably most other cases the effect of cultural heritage is to serve the local economy and to turn religion and ritual into 'culture', blurring distinctions between the secular and the sacred in the new temporality of development.

In the subsequent parts of this Handbook readers will find rituals, divination, their systems, associations and societies as they have been and as they exist now, abundantly revived on their own account, within or despite governmental constraints. 


\section{PART II: REVITALIZED AND MODERNIZING TRADITIONS}

The chapters of Part II are about practices that exist outside formal religious organizations. Chapter 6 , on life-cycle rituals, death, marriage and birth, is the first in Part II. These are of course family-based and the main actors and initiators are householders, not the religious. The rituals they themselves perform or have others perform for them are subject to the changes in the family and the rise of prosperity in the last 40 years. The most elaborate are death rituals, which involve Buddhist or Daoist ritual experts for the salvation of the soul, but also lay masters of ceremony for the transition into ancestorhood. Domestic shrines and ancestral or clan halls have been built or rebuilt. In the cities, on the other hand, many households have transferred domestic care of ancestors to temples. But the main change has been the rising expenditure on banquets and the new institution of annual birthdays. They reflect global aspirations and access to moderate wealth.

Chapter 7 on temples and festivals is again about local people, but in this case how in their territorial communities they select and celebrate gods that have, in their experience, been efficacious. This is now mainly a phenomenon which takes place outside the cities, in towns and villages. But even so it is probably the most pervasive of all the phenomena of ritual and related practice in China beyond those of households and families for themselves. After expounding the cults of the effectivity of gods, this chapter rightly turns to the idea of festivity in China, principally the heat and noise of a festive event. The 'red-hot sociality' of the event is the vitality, the abundance of noise, smells, sounds and activity experienced by locals and their visitors. It is a deliberately chaotic liveliness, not organized so that every participant experiences it in the same way, but on the contrary, each experiences the assembly of people met and things consumed, heard, smelled and seen in their own trajectory through the event. Like markets, and indeed including markets, temple festivals are sociable, heated and noisy, and this essential quality complements and manifests the gods' effective response that some of the participants seek individually.

Chapter 8 is on the telling of fate and fortune, but more than that, it introduces the cosmology, which is the universe that encompasses us according to Chinese textual and practical transmission. Often in other parts of the world a cosmology is conveyed by a religion. But in China it is a cosmology conveyed not just in rituals but in food, in medicine, in life-nurturing exercises, and in a great range of techniques of fate-telling 
and the remedying of fate that may accompany religious rituals such as festivals but can also be quite independently practised. These divinatory practices and their cosmology rise to the challenge that promotes 'science' as the criterion of knowledge and truth, by their practitioners and clients claiming they are a Chinese form of science and that they hold by the calculations and predictions of all scientific methods.

Another response to the demands of twentieth-century modernization and science was the formation of redemptive societies, which are the subject of Chapter 9. They conformed to the newly translated concept of religions, each of them claiming to be as universalistic as Christianity and other world religions, yet drawing from Chinese traditions as well, including those of self-cultivation in Daoist and Buddhist aspirations to transcendence and world salvation. They proselityzed, many of them met in congregations, and they engaged in the 'industrial' philanthropy that was formed in the twentieth century (see Chapter 2). In their missions to redeem moral rectitude for themselves, in their own organizations and in the rest of society, their standards in most cases were those of Confucian teaching. Though they flourished, their relationship to the Nationalist Party in government was tense, subject to campaigns against superstition, but more relaxed when the Confucianism of Chiang Kaishek's New Life Movement was more in harmony with their aims. Adaptability worked under Japanese colonization, in Hong Kong, and in Taiwan, but was impossible under the PRC during the Mao years. Now one of the redemptive societies, the Yiguandao, has resurged not only in Taiwan but also in mainland China.

\section{PART III: DAOISM, BUDDHISM, TIBET, THE NAXI}

Part III begins in Chapter 10 with household-based Daoists, who provide services for festivals and for domestic occasions, particularly death rituals, alongside Buddhists and with similar liturgies. This chapter is a bridge between Parts II and III. It provides details on the ritual sequences the ritual experts perform, stressing their musical and rhythmic performance without which the mere texts of ritual handbooks and scriptures cannot be understood. Because it is based on fieldwork among homebased Daoists and ritual music associations in northern China, referring also to similar fieldwork studies and films from southern China, this chapter conveys a strong sense of local variation among ritual traditions. Contributing to this variation are Buddhist ritual experts, some based in small temples. They may be celibate but they perform the same ritual services that the household Daoists provide, with their own variations, 
but all share Confucian conceptions of virtue and Buddhist conceptions of afterlife. Buddhist monks and nuns in monasteries do not provide these ritual services to the lay population.

Daoism as self-cultivation and for ritual effect, in particular organized Daoism, is the subject of Chapter 11. There is overlap with the ritual services provided by home-based Daoists. 'Religion', organized as well as dispersed, in China is not made up of communities of faith except for the religions of monotheistic faith and in the more apocalyptic redemptive societies. But there are different authorities and differentiated lines of transmission, the lineages of master-disciple learning. In contemporary China, the state-organized patriotic associations overarching and to some extent replacing these lineages have had the effect of turning rituals into culture and subjecting them to Sinicization. The popularity of Daoist and Buddhist self-cultivation globally and within China is beyond centrally organized control, but it is conducive to the idea of Chinese civilization promoted by the Party.

Celibate Buddhists and monastic Buddhism have much in common with monastic Daoists, as Chapter 11 points out. Chapter 12 outlines the extensive early twentieth-century reform of Buddhist traditions by charismatic Buddhist monks, which included a moral basis for the new order of the nation and institutions of education and welfare attached to monasteries. After destruction of nearly all monasteries and the dispersal of their monks and nuns, there were still sufficient numbers of these reform Buddhists alive to lead a very substantial revival of Buddhist monasteries from the 1980s onwards. Chapter 12 illustrates this through the example of the history and present observation of a large Chan Buddhist nunnery in Jiangxi province and the biography of its nun abbot. The success of this and other monastic Buddhist establishments and their large number contrasts with the fewer Daoist monasteries. Buddhists have succeeded in setting up their own pedagogy, in which a lay patriotic curriculum forms a proportionately small part, smaller than its equivalent in the training of Daoist monastics. Even so, it conforms closely with standards determined through the central organization of the national Buddhist Association. More purist monks, critical of these standards, are relatively powerless.

Another Buddhism that spread from India through Tibet to many of the provinces of China and to its capital is the subject of Chapter 13. The inter-sectarian rivalry and the dominance of the Dalai Lama's Gelug Pa sect's attempts to eliminate the others was halted by the secular government of the Chinese Communist Party. The result is that there are many Tibetan Buddhisms, though all are subject to Communist controls, particularly in the Tibetan Autonomous Region, the exertion of which 
had led to the self-exile of the Dalai Lama. Another unintended outcome of these controls has been, through heavy restrictions on monks' and lamas' foreign travel, the extension of pilgrimages to and from other parts of China, in both directions, and the increasing Han Chinese attraction to Tibetan Buddhism.

The pre-Buddhist religion of Tibetan civilization, the Bon, still exists in two forms. One that is combined with Buddhism has several large monasteries. The other, whose ritual experts are shamans, is closely related to the death and ancestral rituals of spirit journeys performed by $\mathrm{Na}$ and other Tibeto-Burmese peoples, which is the subject of Chapter 14. As in almost every chapter, the most important rituals are those that turn a person who has died into an ancestor. So too in the case of the subjects of Chapter 14, for whom the rites perform a spirit journey through many generations and locations back to the mountain by which the couple that gave birth to humans came to earth.

Separation is the main drama and problem. Rites at death and in veneration of ancestors reconnect those separated by death and by migration. As well as conceiving of the human spirit as separable from bodies and becoming trapped and harmful ghosts in cases of violent or untraced deaths, the $\mathrm{Na}$ also have a word for the spirit of life, whose drift away from the house, its animals and its land, at various crucial life events, threatens the household with illness and misfortune, and so rites to bring about its return must be performed. The performers of these death and healing rites are dongba, shamanic experts whose pictographic books are also called dongba. By all these means the Na make sense of their histories and the distant causes of their dislocations in more recent years of political violence.

\section{PART IV: ISLAM AND CHRISTIANITY}

There is a strong tendency in PRC religious policy to identify Islam with ethnic minorities, even the physically indistinguishable Hui, descendants of marriages between Arab and other traders with Han Chinese. But as Chapter 15 points out, there are also purely Han Chinese converts to Islam, now and presumably in previous times. Yet they too are categorized as Hui, an ethnicity. Muslims in China, as everywhere, distinguish themselves for themselves by their religious practices, their clothing and their prohibitions, but inevitably this also means engagement with co-nationals, in China particularly through the prohibition against eating pork, which is one of the main meats (the other is chicken) in Chinese cuisine. One prominent strand of Islam in contemporary China is like the 
redemptive societies of the early twentieth century (see Chapter 9 of this Handbook), seeking moral redemption, including Confucian virtues, of the Chinese nation and its society and thence the world by its total adoption of Islam. The prescribers of this movement call themselves Hui. They represent what this chapter calls a paradox of recognition, the effort to identify themselves as the elite of China, which only marks off their difference from the ruling elite, and the exclusion of other Muslims in China, chiefly the Uighur. The chapter also makes clear, with introductory and concluding detail, how varied the self-designated Hui Muslims actually are. But something of this paradox of recognition could well be a more or less common ground on occasions when Hui pay any attention to their place in the Chinese nation.

Hui live in all Chinese provinces, including Xinjiang where they and the Uighurs (and other Turkic language groups) keep their Islam entirely separate from each other. Chapter 16 tells the recent history of tolerance of Uighur Islam giving way to the fierce restrictions, including the re-education camps, suppressing virtually any public worship or other rituals and restricting every display of Muslim belonging. The result is the survival and feminization of traditional Uighur observances in the domestic sphere, often without the assistance of Muslim ritual leaders. (A previous suppression of Islam in the Ming dynasty also led to a shortage of imams, and to the Chinese Muslim innovation of the training of female imams and female mosques that persist among the Hui ${ }^{4}$.) Domestic Islam of an Uighur tradition focusing on the spirits of the dead thus also escapes from the more scripture-based reformist Islam that was beginning to prevail in much of Xinjiang.

Islam bears the stigma of the stereotype of violent jihad in China, as it does everywhere else in the world. Christianity bears another stigma: its association with Euro-American imperialism. So the insistence of the PRC on the patriotic Three-Self organizations of Protestant and Catholic Christianity, including self-funding and Chinese appointment of church leaders and hierarchy, has deliberately rather than accidentally nurtured a Chinese Christianity. In fact Protestantism has grown most outside the official organization and since the 1980s has been the fastest-growing religion in China, now estimated to have close to 100 million followers.

Chapter 17 traces the history of the Three-Self patriotic Protestant churches and their accommodation to the state pressures to purge themselves of any subservience to imperialist, missionary remnants and

4 Thanks to Tristan Brown for this pertinent observation. See Jaschok and Shui (2000). 
to form a unified institutional system of churches, seminaries, publishers and charity. It also tells of the many refusals to accommodate, on the part of the most evangelical and independent Chinese churches with no history of foreign missionary control. The result is the irony that the most truly independent, Chinese churches have suffered the most persecution by state agencies. Another result is that what was formerly a fragmentary and highly differentiated denominational Protestant Christianity has been unified, if only loosely and in constant wariness against becoming divided into denominations. A second irony is that the greatest growth of Protestant Christianity has been in networks and assemblies that do not register with the unified administration of Protestants.

Independent Chinese networks of Christians seek, without confrontation, to have their own churches independently of any state organization. These are the so-called house churches, both Protestant and Catholic. The subject of Chapter 18 is Protestant house churches. They started as clandestine meetings of Chinese Protestants in each other's houses but now include separate, built churches that are often registered but not subject to the national patriotic association. As the chapter points out, house churches began in rural areas, where they emphasized a miracle-based healing Christianity quite closely related to the exorcistic healing of Daoists and spirit mediums. Their preachers are itinerant and help to create a vast network of house churches. Among them are entirely Chinese versions of Christianity, including evangelizing charismatics, labelled 'sects' and suppressed by government authorities, despite their being exemplars of Sinicized Christianity. But in recent decades and with fast urbanization, independent Protestant church leaders, including some rural preachers, have established their own seminaries and become professional, paid pastors each attached to the congregation of one church and reconciling Christian teaching and morality with material well-being, including businesses within which Christian virtue and teachings are propagated and from which donations to the churches are encouraged.

Among Catholics, the subject of Chapter 19, the equivalent of Protestant house churches are the underground churches independent of the Catholic Patriotic Association. Not being registered or not being affiliated to the central association, but being part of a flourishing network of established communities can be a reason for local governmental authorities to target these churches, house churches, or 'underground' but public churches. But this has reinforced their solidarity. On the other hand, the longer-term process of accommodation between the two, in the Catholic case between what the Chinese state and what the Vatican recognize as bishops, has been a successful internal and external diplomacy. Catholic 
conversions were not individual, but of extended families, urban and rural, local lineages or whole villages. These long-standing communities stood up well to government attacks, but they have been seriously diminished by migration.

\section{CONCLUSION}

From the chapters of this Handbook we can draw some conclusions about religious transformation and realignment in China. Rituals, divination and religions have burgeoned since the opening and reform of the Chinese economy in the 1980s. Their character and growth have been formed by a number of key influences. One is that they have been affected by the policies of a secular state that either treats them with suspicion or controls them as subjects of inherited culture, in a policy that has increasingly stressed the inflection of socialism of the ruling Party by the civilization of China. This was always so in Taiwan, but less controlling and concerted than in the People's Republic of China. The PRC's 1980s campaigns to promote spiritual civilization alongside gains in material livelihood and wealth were followed by campaigns to heighten the quality and culture of its population, and then the more concerted and controlling campaigns of Sinification. The aims of these campaigns have been similar to the Hui Muslim elite's vision of a Chinese Islam, or the Protestant Christian, including evangelical redemptive sects, the syncretic associations, visions of moral redemption, or the new, worldly Buddhism, and the new kinds of religiously organized philanthropic NGOs' formation of new civic selves. They all pursue national regeneration, moral reform, release from ideological crisis, or from the chaos of capitalist greed and competition. But for the secular state, the moral order is cultural and civilizational. Its campaigns have been to assert core controls that have the effect, through the patriotic associations of recognized religions, of turning rituals for magical effects, including healing, and techniques of fate calculation, disciplines of self-cultivation and gifts of spirit possession into Chinese culture, Chinese learning and Chinese knowledge. But many rituals seeking effects, instances of exorcism or of salvation, most forms of divination, and many continuing forms of self-cultivation for transcendence, escape these controls.

Then there are the more incidental and equally strong influences of rising prosperity and of urbanization through regulated, but competitive and fast capitalist growth. Slower versions of capitalist growth and urbanization spurred late nineteenth-century and early twentieth-century 
responses of searches for destiny, for redemptive moral order, or for spiritual havens. All these have been renewed. But post-1980s urbanization, migration to and the growth of cities, has had a much more marked effect in terms of ritual and religious changes. Urban planning and development, including the urbanization of villages, has transformed most dwellings into apartments, with less space for domestic altars and banquets, and turned most neighbourhood temples into dust under property developments of housing, headquarters, industrial and commercial districts. Banquets for life passage ritual occasions have become more widespread, but in professional catering establishments. Diviners, some using statues of deities, provide their services independently. The bigger Daoist or Buddhist temples and their monks and nuns look after lamps for the souls of the dead; churches and mosques outside Xinjiang perform services for their dead. Most ritual services are performed in homes and they have been shortened as the tastes of the young have changed. But the disciplines of self-cultivation brought into the present through transmission of the various ritual traditions in China have flourished, have become global in their reach, alongside academic interest in them, and have been nurtured by new masters. At the same time, New Age spiritualities, business-success groups, and zealots of the cultivation of virtue and the realization of potential among employees, have burgeoned along with industrialized philanthropy.

\section{REFERENCES}

Vermander, Benoit (2019) 'Sinicizing religions, Sinicizing religious studies', Religions, 25 February. MDPI Creative Commons open access. https:/doi.org/10.3390/rel10020137. Yaschok, Maria and Shui Jingjun (2000) The History of Women's Mosques in Chinese Islam. London: Routledge Curzon. 